\title{
41. THE MIDDLE AMERICA TRENCH IN THE GEOLOGICAL FRAMEWORK OF CENTRAL AMERICA1
}

\author{
J. Aubouin, ${ }^{2}$ J. Azéma, ${ }^{2}$ J.-Ch. Carfantan, ${ }^{3}$ A. Demant, ${ }^{4}$ C. Rangin,${ }^{2}$ M. Tardy, ${ }^{5}$ J. Tournon ${ }^{6}$
}

\begin{abstract}
The tectonic framework of the Middle America Trench is composite. In its northern part, the Trench runs along the North American continent (at the least, along Mexico up to the Guatemala Transverse Zone; at the most, up to the Honduras Platform). In this part the Trench is not related to the tectonic features of Mexico, which it cuts very obliquely, and is thus a recent neotectonic feature. In its southern part, the Isthmus of Central America is a tectonic edifice (with a strike like that of the Trench) supporting a huge Tertiary volcanic cover; in this part, the Trench could have originated from an ancient subduction zone involving Mesozoic oceanic sediments and crust.

Along the Guatemala Transverse Zone the following events took place: at the end of the Cretaceous, a big overthrust of Central American-Caribbean ophiolitic facies occurred towards the north, at the termination of the North American continent; and during the Pliocene to Quaternary there was a strong sinistral strike slip motion along the Quaternary there was a strong sinistral strike slip motion along the Polochic-Motagua Fault Zone.

One should note that the division of the Middle America Trench by the Tehuantepec Ridge does not correspond to the tectonic or the neotectonic division of Central America along the Guatemala Transverse Zone or the PolochicMotagua Fault Zone.

Presently the Middle America Trench is a neotectonic feature. Its northern part, the Acapulco Trench, could have been initiated by a large sinistral strike slip motion giving to the Honduras Platform an offset of about $800 \mathrm{~km}$ with regard to the Oaxaca Platform and cutting the Mexican structure off. Whereas its southern part, the Guatemala Trench, could have resulted from a long-lived subduction zone, perhaps related to the Franciscan subduction zone of North America.

The occurrence of Upper Jurassic-Cretaceous-Tertiary oceanic sediments in the slope of the Guatemala Trench, as well as in the Nicoya Complex of Costa Rica, is a strong argument against the generally accepted idea of a Pacific origin for the Caribbean Plate, which can be better understood as a part of the Tethys.
\end{abstract}

\section{INTRODUCTION}

The Middle America Trench marks the Cocos Plate subduction under Central America. It is unique amongst the circum-Pacific trenches because of its composite nature with respect to features on the oceanic plate and the subaerial geological features of Central America (Fig. 1). On its seaward side the aseismic Tehuantepec Ridge divides the Trench into two parts. To the north is the Acapulo Trench, bordered by the Tamayo Transform Fault, which is part of the East Pacific Rise (Fig. 2 ), and to the south is the Guatemala Trench, limited by the aseismic Cocos Ridge. On its landward side to the north of the Polochic-Motagua Fault the Middle America Trench borders southern Mexico, the end of the North American continent, whereas to the south it borders Central America, which is partly a volcanic construction connected with the subduction. These divisions are not the same on the oceanic side as on the continental side: the Tehuantepec Ridge and the Polochic-Motagua area are out of line by nearly $400 \mathrm{~km}$ (approximately

\footnotetext{
${ }^{1}$ Aubouin, J., von Huene, R., et al., Init. Repts. DSDP, 67: Washington (U.S. Govt. Printing Office).

2 Département de Géotectonique, Université Pierre et Marie Curie, 4, Place Jussieu, 75230 Paris, France, Cédex 05.

${ }^{3}$ Instituto de Geologia, Universidad Nacional Autonoma de Mexico, Mexico et Université de Savoic, B. P. 1104, 73011 Chambéry, France.

${ }^{4}$ Laboratoire de Pétrologie, Université de Provence, Centre Saint-Jérôme, 13397 Marseille, France, Cédex 04.

5 Département des Sciences de la Terre, Université de Savoie, B. P. 1104, 73011 Cham. béry, France.

6 Laboratoire de Pétrographie, Université Pierre et Marie Curie, 4, Place Jussieu, 75230
6 . France. Paris, France, Cédex 05.
}

200 miles). Thus the Guatemala Trench borders both southern Mexico and central America and is in this sense composite, in contrast to the Acapulco Trench. Our study focuses on the position of the Guatemala Trench in the geological framework of Central America.

\section{GEOLOGY OF MEXICO: THE END OF THE NORTH AMERICAN CORDILLERAS}

The Cordillera of Mexico (Cordoba et al., 1980; Tardy, 1980) is, like all chains, the result of superimposed tectonic episodes (Aubouin, 1973) in the course of ages, the effects of which are all the more apparent as they are the more recent. It is therefore efficient to order our study from the most recent to the most ancient structures, thus taking a retrotectonic approach.

\section{Neotectonic Framework of Mexico}

In the structure of Mexico, the neotectonic fabric is most apparent, the main aspects of which are: the Gulf of California, the Transmexican volcanic axis, the Middle America Trench, and the Tehuantepec Isthmus.

The Gulf of California (Sea of Cortès) corresponds to a recent oceanic opening along the extension of the East Pacific Rise. To the south the limit is the Tamayo transform complex and to the north, the San Andreas transform complex; inside the Gulf a number of transform faults have been found. The nature of the structure of the Gulf has now been well established by DSDP Legs 64 and 65 and the CYAMEX and RITA deep-sea dives (1981). The recent oceanic opening is not older 


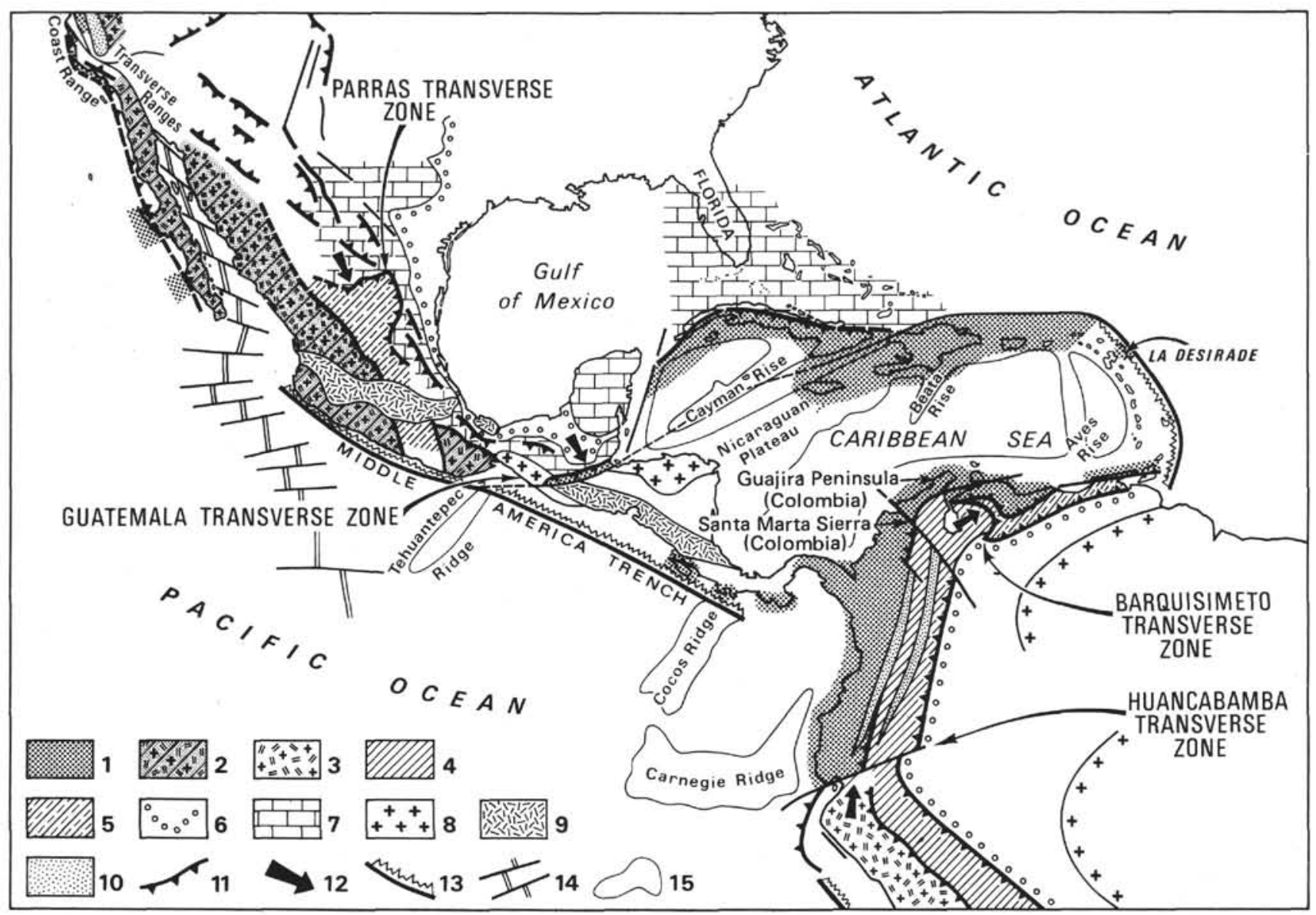

Figure 1. Location of the Middle America Trench in the general framework of North and South America and the Caribbean area (Aubouin and Tardy, 1980). (1. Paleoceanic zones with ophiolites. 2. Volcanic cordilleran zones. 3. Volcanic Andean zones. 4. Nonvolcanic Andean zones. 5. Nonvolcanic cordilleran zones and/or flysch nappes. 6. Molassic foredeep. 7. Continental platform. 8. Continental basement. 9. Pliocene-Quaternary volcanism. 10. Pliocene-Quaternary basins. 11. Overthrust [nappes]. 12. Axial inflexions. 13. Recent subduction zones. 14. East Pacific Rise and transform faults. 15. Aseismic ridges.)

than 3.5 m.y.; the age of the Sea of Cortes is Pliocene to Quaternary.

The Transmexican volcanic axis is formed by calcalkaline volcanoes built in the course of the Quaternary (Demant, 1978). It is bordered to the north by a Pliocene volcanic edifice that shows a very close association of ignimbrites and andesites. The fact that the Pliocene edifice is dissected by a number of vertical faults demonstrates that important structural changes took place between the Pliocene and the Quaternary volcanic sequences. These changes are probably related to the reorganization of the Pacific Plate at the end of the Pliocene (Mammerickx, 1979). The faults along which the Quaternary volcanoes are aligned are not the result of recent subduction, but are the scars left by neotectonic events affecting southern Mexico, that is, the opening of the Gulf of California on the one hand and the birth of the Middle America Trench on the other. The Transmexican volcanic axis has thus been interpreted by some as a product of volcanism associated with a transform complex developed when the opening of the Sea of Cortes took place along the prolongation of the Tamayo Fault (Gastil et al., 1979). Because of its calc-alkaline nature, however, most researchers associ- ate the Transmexican volcanic axis with the subduction of the Cocos Plate, although it is not parallel to the Middle America Trench and although a hiatus of over 400 to $600 \mathrm{~km}$ separates it from the Central American volcanic chain, which is clearly connected with the subduction.

The Middle America Trench itself is recent, Pliocene to Quaternary, or, at the most, late Miocene. In its northern segment it intersects the axis of the structures of the Sierra Madre del Sur at $45^{\circ}$ and distorts the Miocene terranes (see the discussion that follows).

The Tehuantepec Ridge, which is the seaward marker for the start of the wide continental margin characteristic of the Guatemala Trench, corresponds on land to a saddle that determinates the Tehuantepec Isthmus. The Ridge only slightly offsets the structures of southern Mexico (Cordoba et al., 1980) (see the following sections), the strike of which is not disturbed, and it plays no part whatever in the distribution of volcanism. There are no volcanoes on the Isthmus; the nearest are located near the boundary between Mexico and Guatemala, aligned with the faulted area of Polochic-Motagua. The Tehuantepec Isthmus may be a neotectonic secondary line in comparison to the Transmexican volcanic axis 


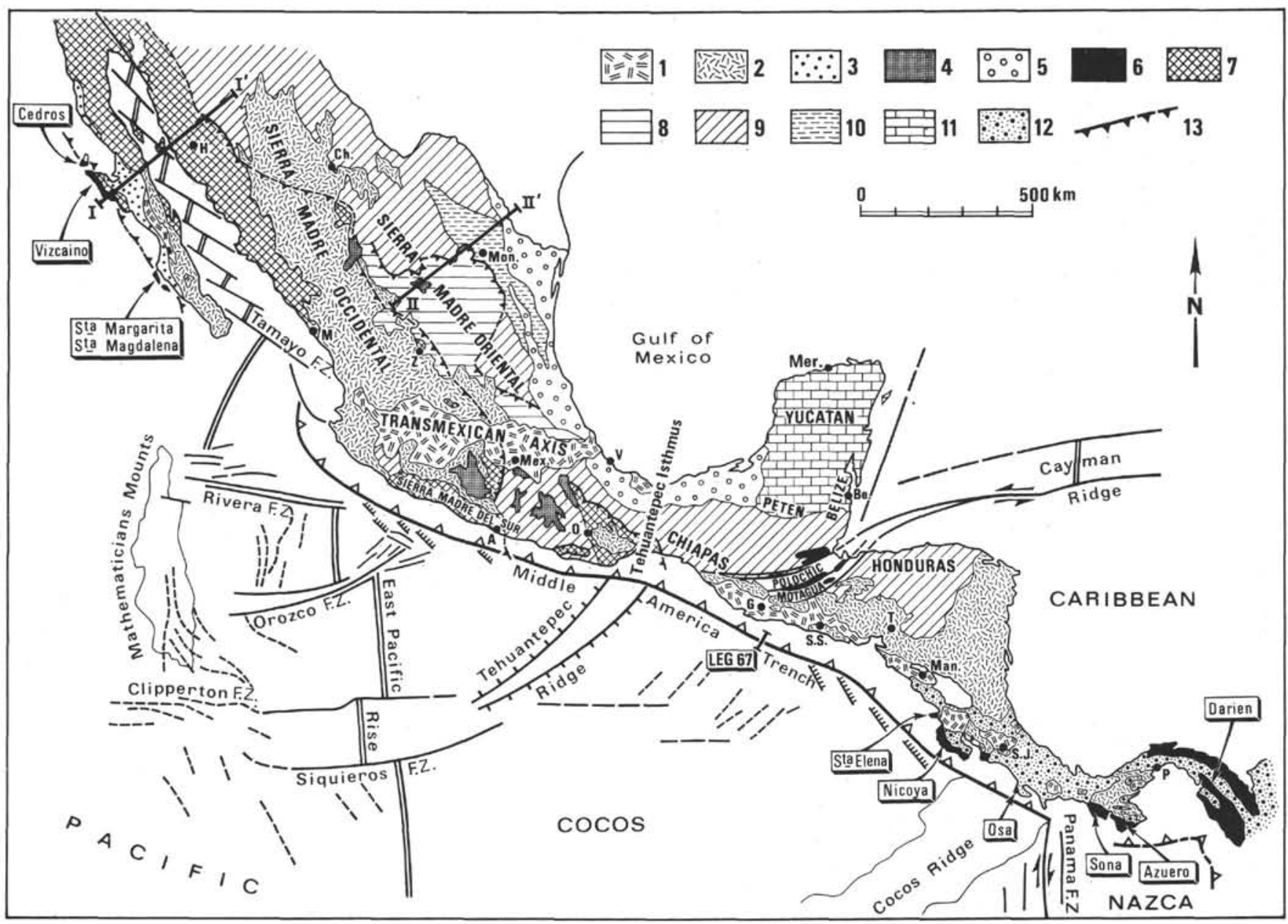

Figure 2. Geologic sketch map showing the main Mesozoic and Cenozoic structural areas of Mexico and Central America. (1-2. Recent volcanism: 1. Pliocene and Quaternary; 2. Oligocene and Miocene. 3-5. Late tectonic formations: 3. unconformable terrigenous marine terranes [molasse] deposited in the Cretaceous to Cenozoic [Baja California]; 4. unconformable terrigenous continental terranes [molasse] deposited in the Eocene to Miocene [Mexican altiplano]; 5. terrigenous marine terranes deposited in the Eocene to Miocene [Gulf of Mexico coastal plain]. 6. Oceanic Mesozoic complexes: A. ophiolitic with blueschists [Baja California: Cedros, Vizcaino, Santa Margarita, Santa Magdalena; Guatemala: Polochic-Motagua Zone] or without [Costa Rica: Santa Elena]; B. tholeitic and volcaniclastic deposited in the Late Jurassic(?)-Early Cretaceous-Late Cretaceous [Costa Rica: Nicoya, Osa; Panama: Sona, Azuero]; C. tholeiitic and volcaniclastic deposited in the Late Cretaceous [Panama: Darien]. 7. Western Sierra Madre terranes [Mexico]: volcaniclastic belt deposited in the Triassic-Jurassic-Early Cretaceous. 8-10. Eastern Sierra Madre terranes [Mexico]: nonvolcanic belt deposited in the [Triassic] Jurassic-Cretaceous: 8. allochthonous terranes including flysch nappes; 9. autochthonous platform of Texas, Coahuila, San Luis Potosi, Oaxaca, Chiapas, Honduras, with Paleozoic basement [Oaxaca, Honduras]; 10. Sabinas Basin. 11. Cenozoic platform of Yucatan, Peten, Belíze. 12. Cenozoic formations of southern Central America. 13. Main overthrusts [front of the nappes]. A., Acapulco; Be., Belíze; Ch., Chihuahua; G., Guatemala City; H., Hermosillo; M., Mazatlán; Man., Managua; Mer., Merida; Mex., Mexico; Mon., Monterrey; O., Oaxaca; P., Panama; S.J., San José de Costa Rica; S.S., San Salvador; T., Tegucigalpa; V., Vera Cruz; Z., Zacatecas. $\mathrm{I}^{-\mathrm{I}^{\prime}}=$ cross section of Fig. 3; II-II' = cross section of Fig. 4.)

and, as we shall suggest, the faulted area of PolochicMotagua.

The neotectonic framework of Mexico cannot be reduced to the few main lines briefly described above. Neotectonic features are apparent everywhere-all over northwestern Mexico there is a faulted area with a basin-and-range-type structure that seems to predate the opening of the Gulf of California, which is not parallel to these structures. This fault net seems to show a first stage of the dislocation of the North American continent but was later interrupted by the opening of the Gulf of California.

The Gulf of California, the Transmexican volcanic axis, and the Middle America Trench form, as a whole, a coherent neotectonic complex connected with the dis- tribution of the plates in this area of the Pacific. The Tamayo Fault, which limits the Cocos Plate, is a transform fault linking the East Pacific Rise to the Middle America Trench: northwards is a pure oceanic-opening framework - that of the Gulf of California; southwards is a subduction framework - that of the Middle America Trench; on land, the Transmexican volcanic axis marks the boundary of these two areas in the prolongation of the Tamayo Fault. These neotectonic structures, no older than the late Miocene or perhaps even the early Pliocene, seem to have developed in two stages: first the beginning of the dislocation of Mexico into a basin-andrange province, followed by the present-day configuration, with the opening of the Gulf of California and subduction along the Middle America Trench. 
This neotectonic framework is related to the oblique collision between North America and the East Pacific Rise that took place north of the Tamayo Fault while subduction continued in the south.

\section{Tectonic Framework of Mexico}

The structure developed in Mexico in the course of the alpine Mesozoic and Cenozoic cycles is a clear extension of the tectonic events that occurred in western North America.

\section{Northern Mexico, North of the Transmexican Volcanic Axis}

In this area from the Pacific coast (to the west) to the Gulf of Mexico (to the east) one can recognize (Figs. 1 and 2): (1) The extension of the California Coast Range units, which crop out in Vizcaino Peninsula and adjacent islands (Cedros, Margarita, Magdalena) along the present Baja California borderland (Rangin, 1978). On these islands ophiolites comparable to those present at the base of the Great Valley sequence of California are overthrust westward on top of Franciscan-type units (blueschists and melanges). This contact is the southern extension in Mexico of the Coast Range thrust of California (Jones et al., 1976). Both terranes are disconformably covered by molasse-type deposits, an equivalent of the Great Valley sequence of California.

(2) These westernmost units are overthrust to the west by a Mesozoic volcanic-plutonic assemblage of units, including various arc-type terranes, built along the North American continental borderland.

The oldest units (the San Andrés complex in Baja California and the Sonoran magmatic belt in adjacent mainland Mexico), deposited in the Jurassic, were initially tectonized in the Late Jurassic (Nevadian event). They are disconformably covered by an extensive Early Cretaceous volcanic-arc-type terrane (Alisitos Formation). This volcanic arc interfingers eastward with the coeval detrital and carbonated sediments of the Chihuahua-Sonora Basin, an extension of the Caribbean seaways to the Northeast in the Early Cretaceous.

These Mesozoic volcanic-plutonic units thrust westward over the Franciscan-type terrane and, more modestly, eastward over the sedimentary Chihuahua-Sonora Basin in the Middle Cretaceous (Oregonian event). These volcanic-plutonic complexes are thus located in the core of an asymmetric double overfold (Fig. 3).

The last extensive volcanic episode is represented by the building of the calc-alkaline ignimbrites, rhyolites, and andesites pile of the Sierra Madre Occidental (McDowell and Keizer, 1977; Gastil et al., 1979; Cameron et al., 1980; Lanphere et al., 1980). This Oligocene volcanism, spanning many hundreds of thousands of square kilometers, is considered the result of the subduction of the Farallon Plate under the North American continental borderland. Those Cenozoic ignimbrites reach well beyond the Mexican border, in the western North American Cordillera to the north and in Central America to the south, especially in Guatemala and Honduras (Williams and McBirney, 1969). The bulk of the OligoceneMiocene ignimbrites, which form the vast eastern Sierra
Madre tableland, has developed in alignment with the Gulf of California. Overlying the Eocene-Oligocene andesites and associated with the paleosubduction of the Farallon Plate, the ignimbrites are perhaps connected with the swelling of the crust just before the first basinand-range rifting prior to the opening of the Gulf of California.

In any case, there is a general change in the space distribution and nature of volcanism at the Oligocene/ Miocene boundary ( $2 \mathrm{Ma}$ ). This general alteration is perhaps due to changes in spreading directions and in the relationship between the Pacific Ocean and the American Plate (a change from subduction to collision with the East Pacific Rise prior to the opening of the Gulf of California).

(3) The rest of northern Mexico consists of the sedimentary formations of the eastern Sierra Madre thrust eastwards towards the Gulf of Mexico during the Paleocene Laramian orogenic phase (Cordoba et al., 1980; Tardy, 1980).

The most apparent feature of the eastern Sierra Madre is the Parras Transverse Zone in northern Mexico (Aubouin et al., 1977a). This zone is marked by the axial inflection of the Texas-Cohuila Platform, on which the Parras nappes (comprising Mesozoic limestone nappe and Cretaceous-lower Tertiary nappe) were overthrust at the beginning of the Eocene (Laramian orogenic phase) to the extent of bordering the Gulf of Mexico.

Thick molassic Paleogene and Neogene formations were placed on the Mexican plateau, while flysch continue to pile up on the Gulf of Mexico margin. An intraMiocene tectonic episode developed wide radius folds that deformed the previous structures. This tectonic event was followed by the piling up of Pliocene-Quaternary deposits in the neotectonic rift valley, born of the basin-and-range tectonics, from the late Miocene onward.

(4) With the exception of the opening of the Gulf of California, Mexico appears as an edifice with a double vergence on either side of a Mesozoic volcanic-plutonic calc-alkaline axis developed in the western Sierra Madre and Baja California-as internal zones common to the Franciscan and Mexican systems (Cordoba et al., 1980). There are at least two metamorphic belts: a high pressure-low temperature zone of blueschists to the west in the Franciscan system of western Baja California; and a low pressure-low temperature zone of greenschists to the east, in the western Sierra Madre and eastern Baja California. On the western side, the tectonic features of the Franciscan system face west; on the eastern side, the features of the Mexican system face east. The Mexican system is the seat of the earliest tectonic episodes which began in the Late Jurassic, while the most recent phases moved together: westwards in the west (in the Franciscan system), eastwards in the east (in the Mexican system) in the Middle Cretaceous, the Late Cretaceous to early Eocene, and the Tertiary. The nature of the two sides differs fundamentally. To the west (Fig. 3) the Coast Range is formed by the piling up of the Franciscan paleoceanic units, whereas to the east (Fig. 4), the Sierra Madre is formed by Mexican epicontinental sedi- 


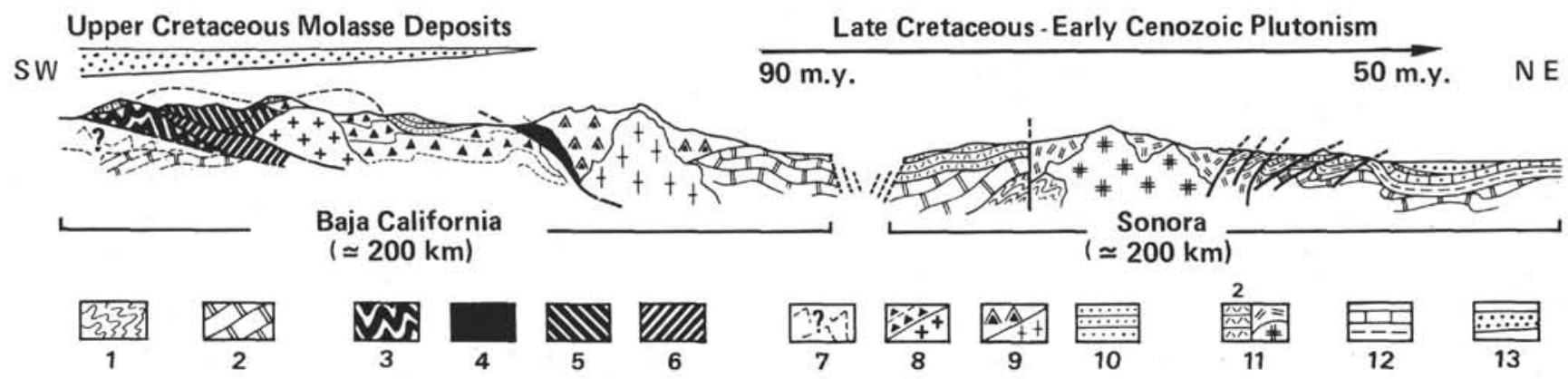

Figure 3. Schematic cross section of the Californian-Cordilleran edifice in Baja California and Sonora (Cordoba et al., 1980). (This location is shown as I-I' on Fig. 2. 1-2. Basement: 1. Precambrian metamorphic basement; 2. Precambrian and Paleozoic nonmetamorphic basement. 3-10. Californian terranes: 3. blueschist facies metamorphic terranes; 4-6. ophiolitic terranes deposited in the Triassic to the Jurassic [4. Triassic, 5. Callovian, 6. Callovian-Tithonian]; 7-9. volcanic-plutonic complex deposited in the Triassic to the Early Cretaceous [7. TriassicLias(?), 8. Late Jurassic: Callovian-Tithonian, 9. Early Cretaceous]; 10. Albian flysch [nappe]. 11-13. Cordilleran terranes: 11. volcanic-plutonic complex deposited in the Jurassic [Lias-Oxfordian]; 12-13. nonvolcanic sedimentation series deposited in the Cretaceous; [12. Early Cretaceous; 13. unconformable Early Cretaceous-molasse]. For better representation, Upper Cretaceous molasse deposits and Upper Cretaceous-lower Cenozoic plutonism were omitted.)

SW

Sierra Madre Oriental

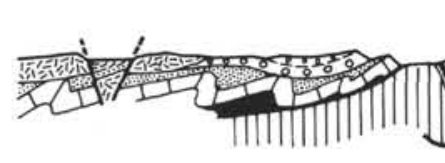

血血1

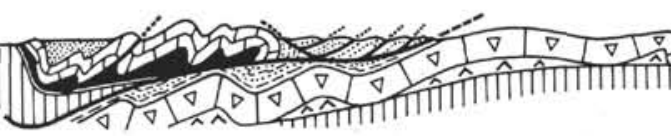

Coahuila Platform

Gulf of Mexico

Coastal Plain

NE

Figure 4. Schematic geological cross section of the Sierra Madre Oriental (Cordoba et al., 1980). (The location is shown as II-II' on Fig. 2. 1. PreJurassic basement. 2. Callovian-Oxfordian décollement level [gypsum]. 3-6. Sierra Madre Oriental: 3. Oligocene-Miocene andesitic and ignimbritic volcanism; 4. unconformable Eocene-Miocene sedimentary terranes [molasse]; 5. Upper Cretaceous flysch; 6. Jurassic-Lower Cretaceous pelagic limestones. 7-8. Coahuila Platform: 7. Lower Cretaceous rudist limestones; 8. Lower Cretaceous décollement level [gypsum]. 9-10. Gulf of Mexico Coastal Plain: 9. Jurassic-Cretaceous platform to pelagic limestones; 10. Cenozoic terrigenous terranes.)

mentary (eastern Sierra Madre) and volcanic-plutonic (western Sierra Madre) units.

The whole picture is that of a tectonic edifice connected to the Pacific (paleo)subduction during the Mesozoic and the Tertiary (see for comparison Ernst, 1970; Coney and Reynolds, 1977), with the oceanic Baja California Franciscan series subducted beneath a distorted continental margin of the Sierra Madre Mexican series and all run through by plutons and calc-alkaline volcanoes of Baja California and the western Sierra Madre.

One therefore finds in northern Mexico an extension of the structures of the Cordilleras of western North America. A mesozoic volcanic-plutonic calc-alkaline axis is equivalent to that of the Sierra Nevada, which corresponds to episodes of subduction of the Pacific Plate as recorded by the Franciscan rocks tectonically stacked against the western face of Baja California and California. These act as internal zones to a Mexican tectonic edifice, overthrusted eastwards, equivalent to the Cordilleras of western North America from the Sierra Nevada to the front of the Rocky Mountains.

\section{Southern Mexico, South of the Transmexican Volcanic Axis}

South of the Transmexican volcanic axis, the northern Mexican structures continue in the Sierra Madre del
Sur to such an extent that the plateau zone becomes reduced at the Rio Tehuacan Valley and the continuation of the Coast Range is lost (Cordoba et al., 1980). The Sierra Madre del Sur is thus equivalent to the western and eastern Sierra Madre, the tectonic orientation of which, almost north to south, dies out at the coast at its intersection with the Middle America Trench. There is no prolongation of the Franciscan complex in southern Mexico.

On the contrary, zones more external than the eastern Sierra Madre appear in the Yucatan-Peten-Belize country and the Chiapas Chain. They are affected by the more recent episodes of tectonic folding during the Miocene, terminating with frontal overthrust onto the southern Yucatan Miocene molasse. The Middle Cretaceous and Late Cretaceous phases are mainly apparent in the western zones of the chain in the Sierra de Juarez and the Oaxaca block of the western cordillera system. The Miocene tectonic phase thus completes the polarity of the Mexican chain, starting from its internal volcanicplutonic axis (see the preceding sections).

Metamorphism is important in the west of the Sierra Madre del Sur and is an extension of the western Sierra Madre metamorphism. A large part of the metamorphic terranes formerly considered Precambrian or Paleozoic are in fact Jurassic to Cretaceous, such as further north 
in the western Sierra Madre. These dates are substantiated by discoveries of fossils during the last few years (Cordoba et al., 1980). These metamorphic series, overthrust eastwards onto the sedimentary cover of the eastern Sierra Madre, constitute a type of "schistes lustrés" terrane.

The magnitude of the overthrust of the Mesozoic matamorphic facies is emphasized by the vast sheet of metamorphic rocks overthrust from the west as far as the neighborhood of Tehuantepec, and preserved forward of the Oaxaca block at the foot of a fault zone striking NNW-SSE (Fig. 2). These structures are only slightly disrupted at the Tehuantepec Isthmus. The Sierra Madre de Chiapas is aligned with the most external parts of the Sierra Madre del Sur. The Miocene distortions are very amply marked there; in some aspects the Sierra Madre de Chiapas appears like a kind of Jura mountain range, the front of which thrusts over the Yucatan Platform.

Associated with these metamorphic facies, the first ophiolitic bodies appear, unknown in the northern Mexican chain. This is the first evidence of an ophiolitic belt present in Mexico and is probably linked to the Caribbean area (see the discussion that follows).

\section{Conclusion}

Mexico is the prolongation of the western mountain system of North America with a few characteristic changes due to: the recent superposition of the American continental margin on the East Pacific Rise, which caused the basin-and-range structure and the opening of the Gulf of California; the outline of the Gulf of Mexico, thanks to which more and more eastern external zones developed towards the south, in such a way that the front of the eastern Sierra Madre, Paleocene in the north of Mexico, becomes Miocene in the south; and the obliquity of the Middle America Trench, which reduces southern Mexico to relatively external areas of the Mexican system while the Californian Coast Range is terminated.

Off the coast of Mexico, the Middle American Trench runs along a continental border.

\section{TRANSVERSE ZONE OF GUATEMALA: THE TRANSITION TO CENTRAL AMERICA AND THE CARIBBEAN AREA}

Within Guatemala, the volcanic cordillera begins and widens in the Central America Isthmus. This arrangement features calc-alkaline volcanoes and is separated from those on the Transmexican axis by approximately 400 to $600 \mathrm{~km}$. There are no active volcanoes along the Pacific coast of southern Mexico; the classical association of trench and volcanoes occurs only within Central America.

The most outstanding neotectonic feature is the Polochic and Motagua Faults Zone (Dengo, 1973), which, as shown by earthquake focal mechanisms, correspond to a sinsistral strike slip motion. The Antigua-Guatemala "rift valley" opened as a consequence of this motion.
This complex of faults, so obvious on the Caribbean side, does not appear on the Pacific coast.

Nevertheless, should it be confirmed that the Honduras Platform has a constitution similar to that of the Oaxaca block (see preceding discussion), one could suggest that the Polochic-Motagua Fault Zone initiated the Acapulco Trench during the late Miocene through a large sinistral strike slip motion that was afterwards taken up in the subduction of the Cocos Plate.

The Polochic-Motagua Fault Zone is superimposed on a tectonic complex of nappes that overthrust northwards (Wilson, 1974; Aubouin et al., 1977a). The main element is an ophiolitic nappe that was thrust over the Peten Platform, an extension of the Yucatan Platform, at the end of the Cretaceous during the Laramian orogenic phase. The ophiolites are associated with metamorphic high pressure-low temperature rocks of the blueschist facies. The whole tectonic allochthon represents the Caribbean sheet front, which is distorted by the East Yucatan fault complex. A similar allochthon extends eastward onto Cuba and passes north of Hispaniola and Puerto Rico. A tectonic reentrant of this Caribbean thrust front is preserved in southern Mexico thanks to the East Yucatan faults. It would be risky to consider it a semiwindow.

\section{Conclusion}

The Guatemala Transverse Zone (Aubouin et al., 1977 a) is a major feature marked in two ways. First, at the end of the Cretaceous, the Caribbean nappes were thrust northward on the axial inflection of the southern Mexico structures. In this respect, the Guatemala Transverse Zone is parallel to the Parras Transverse Zone of northern Mexico (see preceding discussion) and in general alignment with the various transverse zones that segment the western North American Cordilleras. Second, at sometime during the Miocene to Quaternary, the west to east sinistral strike slip of the Polochic and Motagua faults may have offset Central America toward the east with respect to Mexico.

Given our present knowledge, we cannot specify the prolongation of the ophiolites and the metamorphic facies of the Guatemala Transverse Zone into Mexico. Do they link up with the Franciscan facies to the west? To the north, are they continuous with the metamorphic facies and the ophiolites of the internal part of the Sierra Madre del Sur (see earlier discussion)? At first thought, the second hypothesis seems the more likely: the Caribbean area would extend northward in the shape of the finger of a glove ("en doigt de gant") east of the Mesozoic plutonic-volcanic arc that borders the Mexican system on the Pacific side (Cordoba et al., 1980). But to be sure of these relationships between the Caribbean and Sierra Madre, we must know more about the magnitude of the offset along the Polochic-Motagua Zone.

Today, the North American continent extends up to the Guatemala Transverse Zone, where it abuts the Caribbean nappes that have been displaced by the Yucatan fault scarp. 
Up to the Guatemala Transverse Zone, the Middle America Trench continues along the North American continent.

\section{GEOLOGY OF CENTRAL AMERICA}

Central America is essentially a recent volcanic cordillera, stretching from Guatemala to Panama, nevertheless it has been traditionally divided into two parts (Dengo, 1973). The northern part includes nuclear Central America: Guatemala, Honduras, El Salvador, and Nicaragua, the substratum of which is a core of prevolcanic terranes. The southern part is the Isthmus of Central America (Costa Rica and Panama), which is nearly entirely volcanic, although in various peninsulas along the Pacific coast there are outcrops of prevolcanic terranes that differ totally from those of nuclear Central America.

The younger Pliocene-Quaternary volcanoes (Williams, 1960) are the dominant geomorphologic features, but volcanism seems to have started in the Eocene-perhaps in the early Eocene or even at the end of the Paleocene-when the first signs of an andesitic volcanism appeared in Costa Rica. Early Eocene dioritic plutons are known in Panama. Subduction may have thus begun prior to the Miocene.

During the Oligocene and mainly the Miocene and the Pliocene, calc-alkaline volcanism spread over all Central America, from Guatemala to Darien, Panama (Fig. 2) (Robin and Tournon, 1978). It was essentially an andesitic volcanism; however, in nuclear Central America (particularly Honduras) the middle Miocene is marked by an ignimbritic-rhyolitic episode that is contemporaneous with part of the thick ignimbritic extrusions in Mexico (see preceding sections). Dioritic and monzonitic intrusions exist in most of the countries of Central America, where they are associated with "porphyry copper."

During the Quaternary, a line of large andesitic stratovolcanoes was built parallel to the Middle America Trench (Meyer-Abich and McBirney, 1958). In El Salvador, but mainly in Costa Rica (Guanacaste) and Panama (Cocle), there is a wide outcrop of dacitic and rhyodacitic ignimbrites. The alkaline magmatism, small in volume with respect to the calc-alkaline magmatism, is close to the Caribbean coast north of Honduras, but is centered mainly in Nicaragua and Costa Rica where the alkaline lavas of nephelenitic, basanitic, and basaltic composition are Pliocene-Quaternary.

\section{The Honduras Platform}

In the north, including Guatemala, Honduras, and Nicaragua, the widening of nuclear Central America is tied to the presence of Mesozoic prevolcanic terranes (mainly limestone) and Paleozoic sedimentary and metamorphic formations that constitute the Honduras Platform. Precambrian formations are perhaps also present in the west of Guatemala, just below the volcanic terranes along the Pacific coast. These Paleozoic outcrops are nucleii incorporated into the Central American Caribbean chain. Nevertheless, because of their platform structure and nature, they are comparable to those crop- ping out in southern Mexico (e.g., Oaxaca block). They might be the extension of the Mexican structures, whether it be the reappearance of a window of the Peten Platform at the rear of the Caribbean thrust front, or the displacement of a part of the Oaxaca block through a large sinistral strike slip along the Polochic-Motagua Fault Zone (see the previous discussion). In both cases, relatively external elements of the Mexican chain might be found in Honduras, and the Honduras Platform would represent the furthest known extension of the North American continent.

\section{The Nicoya Complex}

In the southern parts of Costa Rica and Panama, the Isthmus of Central America is fringed, along the $\mathrm{Pa}$ cific, at the foot of the Volcanic cordillera, by a tectonized volcanic-sedimentary formation. That formation comprises from north to south the Santa Elena Peninsula, the Nicoya Peninsula, the Osa Peninsula, and the Sona and Azuero peninsulas.

Beneath an upper Campanian-Maestrichtian to Tertiary transgressive sedimentary cover, the Santa Elena Peninsula is exposed as a massif of peridotites including an ophiolitic complex of tectonized harzburgites, gabbros with cumulate facies, and dolerites. These have been overthrust onto a volcanic-sedimentary complex of the diabase-radiolarites type (Azéma and Tournon, 1980).

The Nicoya Peninsula is formed by a volcanic-sedimentary series determined by radiolarian assemblages as Upper Jurassic(?) and Cretaceous (Azéma et al., 1979; Galli, 1979; Schmidt-Effing, 1979). The relation between the Santa Elena peridotites and the Nicoya Complex is unknown. Most probably the Santa Elena peridotites represent a higher unit, tectonized at an early date (prior to the late Campanian-Maestrichtian) and then thrust over the Nicoya Complex.

The Sona and Azuero Peninsulas are covered by an upper Campanian-Maestrichtian transgressive sedimentary sequence (Fig. 2). They include rocks of the greenschists facies, for which there is no equivalent elsewhere in Central America (Recchi, 1976). Their age is still unknown. These rocks are probably part of a volcanic-sedimentary complex, as ancient basalts and graywackes have been identified in the metamorphic terranes.

There is, therefore, along the Central America Isthmus, a tectonic edifice of Pacific vergence, built with oceanic terranes themselves of Pacific origin, and tectonized at the end of the Cretaceous. There is no indication of the presence of a continental basement. The Central America Isthmus is perhaps an intraoceanic edifice.

The Mesozoic terranes of the Pacific coast of the Isthmus of Central America are not related to those of Mexico, unless, possibly, with the Franciscan with which they share a common facies. A detailed comparison remains to be made, which should be governed by the fact that the outcrops in Baja California are the internal parts of the Franciscan system, those that were the earliest tectonized, perhaps as early as the Late Jurassic; the Nicoya series should be compared to the more external, the westernmost, Franciscan formation (see the dis- 
cussion that follows). But what to compare the greenschists of the Sona Azuero peninsulas with?

\section{DISCUSSION}

1. The Middle America Trench skirts the end of the North American continent-at least up to the Guatemala Transverse Zone, at most up to the latitude of the Honduras Platform. This end of the North American continent is a remarkable place from the tectonic point of view. During the Late Cretaceous to the Paleocene, north-south compression between North America and South America was predominant: therefore the Caribbean thrust system was overthrust onto the American Platform as an ophiolitic nappe. At the present time, and since the Pliocene, the predominant movement has been a sinistral west-east strike slip.

The southern part of the Middle America Trench skirts the Central America Isthmus, which is perhaps a purely intra-oceanic construction. This arrangement is very limited in space because the northern part of the South American continent-the Santa Marta Sierra and the Guajira Peninsula in Colombia-is almost on the same latitude as the Honduras Platform; the greenschists of the Sona, Azuero, and Panama peninsulas perhaps begin to belong to the edifice fringing the South American continent.

Although at sea the main boundary is the Tehuantepec Ridge, on land the main boundary is not the Tehuantepec Isthmus, which only offers a very slight offset of the structures, but the Guatemala Transverse Zone. Inversely, the Guatemala Transverse Zone does not seem to be marked at present at its point of intersection with the Middle America Trench. This lack of extension seems to indicate that its sinistral present motion is recent and could be limited to the transversal opening of the Antigua-Guatemala "rift valley."

There are, however, signs of a far more important sinistral strike slip motion during the late Miocene, which caused the Honduras Platform to shift approximately $800 \mathrm{~km}$ eastwards. This motion cut the Mexican structures off and could have initiated the Acapulco Trench as a strike-slip trench subsequently taken up by subduction. The Polochic-Motagua area was perhaps, during the late Miocene, the landward continuation of a Pacific transform fault with a compressive transcurrent motion, hence nonvolcanic. In the same way, perhaps the Transmexican volcanic axis has been, since the Pliocene, the landward continuation of the Tamayo Fault with an extensional transcurrent motion, thus volcanic.

2. South of the Tehuantepec Ridge, structures of the Nicoya and Santa Elena peninsulas may extend under the continental margin. Geophysical information supports this hypothesis (see J. Ladd, this volume). As a whole, the basic Nicoya Complex and the peridotites of the Santa Elena Peninsula bring to mind the Franciscan configuration as it is exposed in the Santa Margarita and Santa Magdalena islands at the extreme point of Baja California. Also, similar facies exist in the western Cordilleras of Colombia. At present we can only speculate that Coast Ranges of the Franciscan type border western North America, Central America, and South America, from California to Colombia.
The Middle America Trench in its southern part is parallel to ancient structures that can be considered connected to episodes of paleosubduction. This position is very different from that of its northern part, where it intersects geologic structures of southern Mexico. The Trench in its present form occupies its ancient position offshore of the Isthmus of Central America (Guatemala Trench), while it occupies a new position offshore of southern Mexico (Acapulco Trench), which can be understood better if a vast sinistral strike-slip offset occurred in the course of the Miocene.

3. The part played by the aseismic Tehuantepec and Cocos ridges is very important on the seaward side, but very weak on the landward side of the Trench. On the oceanic side, both ridges restrict the Trench and limit the width of the large Middle America continental shelf. On the continental side, the Tehuantepec Ridge produces only a slight offset in the structures, whereas the Cocos Ridge raises them as a whole. It is on the "nose", of the Cocos Ridge that the Nicoya Peninsula is elevated. However, neither the Tehuantepec Ridge nor the Cocos Ridge play a part in the continuity of the structures on land. The relationship of tectonics and aseismic ridges is the subject of considerable discussion (Vogt et al., 1976). Aseismic ridges seaward of the Andean Cordillera, the Nazca Ridge, for example, alter neither the continuity nor the nature of the Andean Cordillera. This same independence between oceanic and continental structures is also to be found in detail between the continental margin of Central America and the Cocos Plate, as shown by a Seabeam survey of the Leg 67 area (see Aubouin et al., this volume).

4. Within the Central America Isthmus, the relation between the Caribbean and the Pacific and between North America and South America is problematic. For the geologic past, there are lines of paleontological evidence showing that the Caribbean area of Tethys affinity (Aubouin et al., 1977b) did not open up in the Pacific before the Late Jurassic or the Early Cretaceous. Upper Jurassic rocks indicate there is no oceanic fauna connection; for example, Calpionellas, which exist throughout the Tethys area, are not to be found on the western side of the Americas (Remane, 1980). In contrast, Lower Cretaceous rocks contain the same type of fauna and are widely spread from the Tethys to the eastern Pacific.

At various times faunal communication existed between North and South America. The Middle Cretaceous seems to have been such a period, as is evidenced by the distribution of the vertebrates found on either side of the Caribbean. The Middle Cretaceous was an essential tectonic period in the Caribbean chains in that it possibly marked the first collision of North America with South America. This collision was repeated at the end of the Cretaceous (Laramian orogenic phase) and in the course of the Paleogene (namely in the middle-late Eocene) before the present-day connection that dates back to the late Miocene or, even, the early Pliocene.

The presence of a tectonic edifice along the Pacific face of the Central America Isthmus limits the possibilities for the origin of the Caribbean Plate. The terranes of Pacific origin that are found there, starting in the late Jurassic, were "trapped" by compressive tectonic events 
in their present position. The terranes of the same age in the Caribbean therefore could not have a Pacific origin and could not have been "captured" during episodes of the differential drift between North and South America (Aubouin and Azéma, 1980). The Caribbean Plate is not of Pacific origin; all available evidence indicates its Tethys affinity.

\section{REFERENCES}

Aubouin, J., 1973. Des tectoniques superposées et de leur signification par rapport aux modèles géophysiques: l'exemple des Dinarides; paléotectonique, tectonique, tarditectonique, néotectonique. lere Réun. Ann. Sci. Terre, Paris, p. 51, and Bull. Soc. Geol. Fr., (7) $15: 426-460$.

Aubouin, J., and Azéma, J., 1980. A propos de l'origine de la plaque caraibe: la face pacifique de l'Amérique centrale. C. R. Acad. Sci. Paris, Ser. D, 291:33-37.

Aubouin, J., Blanchet, R., Carfantan, J. C., Rangin, C., Stephan, J. F., and Tardy, M., 1977a. Des Caraïbes aux cordillères nord- et sud-américaines. C. R. Acad. Sci. Paris, Ser. D, 284:1749-1752.

Aubouin, J., Blanchet, R., Stephan, J. F., and Tardy, M., 1977b. Téthys (Mésogée) et Atlantique: données de la géologie. $C . R$. Acad. Sci. Paris, Ser. D, 285:1025-1028.

Aubouin, J., and Tardy, M., 1980. L'Amérique alpine: le domaine caraibe et ses liaisons avec les cordillères nord- et sud-américaines. 26ème Int. Géol. Congr., Paris, Colloque C5, pp. 62-66.

Azéma, J., Sornay, J. and Tournon, J., 1979. Découverte d'Albien supérieur à Ammonites dans le matériel volcano-sédimentaire du "complexe de Nicoya" (province de Guanacaste, Costa Rica). C. R. Somm. Soc. Geol. Fr., 3:129-131.

Azéma, J. and Tournon, J., 1980. La péninsule de Santa Elena, Costa Rica: un massif ultrabasique charrié en marge pacifique de l'Amérique centrale. C. R. Acad. Sci. Paris, Ser. D. 290:9-12.

Cameron, K. L., Cameron, M., Bagby, W. C., Mall, E. S., and Drake, R. E., 1980. Petrologic characteristics of mid-Tertiary volcanic suites, Chihuahua, Mexico. Geology, 8:87-91.

Coney, P. J., and Reynolds, S. J., 1977. Cordilleran Benioff zones. Nature, 270:403-406.

Cordoba, D. A., Tardy, M., Carfantan, J. C., Campa, M. F., and Rangin, C., 1980. Le Mexique mésogéen et le passage au systeme cordillérain. 26ème Congr. Géol. Int., Paris, Colloque C5, pp. $18-29$.

CYAMEX Scientific Team, 1981. First manned submersible dives on the East Pacific Rise at latitude $21^{\circ} \mathrm{N}$ (Project RITA). General results. Mar. Geophys. Res., 4:345-379.

Demant, A., 1978. Caractéristicas del Eje Neovolcanico Transmexicao y sus problemas de interpretacion. Univ. Nac. Auton. Mex. Inst. Geol. Rev., 2:172-187.

Dengo, G., 1973. Estructura geologica, historia tectonica y morfologia de America Central. Publ. Geol. ICAITI, (2nd ed.).

Ernst, W. G., 1970. Tectonic contact between the Franciscan melange and the Great Valley sequence, crustal expression of a late mesozoic Benioff zone. J. Geophys. Res., 75:885-901.

Galli, C., 1979. Ophiolite and island-arc volcanism in Costa Rica. Geol. Soc. Am. Bull., 90:444-452.
Gastil, G., and Jensky, W., 1973. Evidence for strike slip displacement beneath the Transmexican volcanic belt. Stanford Univ. Publ. Geol. Sci., 13:171-180.

Gastil, G., and Krummenacher, D., and Minch, J., 1979. The record of cenozoic volcanism around the Gulf of California. Geol. Soc. Am. Bull., 90:839-857.

Jones, D. L., Blake, M. C., Jr., and Rangin, C., 1976. The four Jurassic belts of northern California and their significance to the geology of the southern California borderland. Aspects of the Geologic History of the California Continental Borderland, Am. Assoc. Pet. Geol. Pac. Sect. Misc. Publ., 24:343-362.

Karig, D. E., Cardwell, R. K., Moore, G. F., and Moore, D. G., 1978. Late Cenozoic subduction and continental margin truncation along the northern Middle America Trench. Geol. Soc. Am. Bull., 89: 265-276.

Lanphere, M. A., Cameron, K. L., and Cameron, M., 1980. Sr isotopic geochemistry of voluminous rhyolitic ignimbrites and related rocks, western Mexico. Nature, 286:594-596.

McBirney, A. R., and Williams, H., 1965. Volcanic history of Nicaragua. Univ. Calif. Berkeley Publ. Geol. Sci., (Vol. 55).

McDowell, F. W., and Keizer, R. P., 1977. Timing of mid-Tertiary volcanism in the Sierra Madre Occidental between Durango City and Mazatlán, Mexico. Geol. Soc. Am. Bull., 88:1479-1487.

Mammerickx, J., 1979. Late Cenozoic reorganization of spreading between the Tamayo and the Rivera fracture zones. Geol. Soc. Am. Abstr. with Progr., 11(7):471. (Abstract)

Meyer-Abich, H., and McBirney, A. R., 1958. Catalogue of active volcanoes: Mexico and Central America. International Volcanology Association.

Rangin, C., 1978. Speculative model of Mesozoic geodynamics, Central Baja California to Northeastern Sonora (Mexico). In Howell, D., and McDougall, C. (Eds.), Mesozoic Symposium, Soc. Econ. Paleontol. Mineral., P-5:85-106.

Recchi, G., 1976. Notas sobre la geologia de Panama. Dir. Gen. Recur. Miner., Panama.

Remane, R., 1980. Calpionellids. In Haq, B. U., and Boersma, A. (Eds.), Introduction to Marine Micropaleonotology: New York (Elsevier), pp. 161-170.

Robin, C., and Tournon, J., 1978. Spatial relations of andesitic and alkaline provinces in Mexico and Central America. Can. J. Earth Sci., 15(10):1633-1641.

Schmidt-Effing, R., 1979. Alter und Genese des Nicoya-Komplexes, einer ozeanischen Pälaokruste (Oberjura bis Eozän) im sudlichen Zentralamerika. Geol. Rundsch., 68(2):457-494.

Tardy, M., 1980. Contribution à l'etude géologique de la Sierra Madre Orientale du Mexique [thèse]. Université de Savoie, ParisChambéry.

Vogt, P. R., Lowrie, A., Bracey, D. R., and Hey, R. N., 1976. Subduction of aseismic ridges: effects on shape, seismicity, and other characteristics of consuming plate boundaries. Geol. Soc. Am. Spec. Pap., 172.

Williams, H., 1960. Volcanic history of the Guatemalan Highlands. Univ. Calif. Berkeley Publ. Geol. Sci., (Vol. 38).

Williams, H., and McBirney, A. R., 1969. Volcanic history of Honduras. Univ. Calif. Berkeley, Publ. Geol. Sci., (Vol. 85).

Wilson, H. H., 1974. Cretaceous sedimentation and orogeny in Nuclear Central America. Am. Assoc. Pet. Geol. Bull., 58:1348-1396. 